\title{
GLS2 wt Allele
}

National Cancer Institute

\section{Source}

National Cancer Institute. GLS2 wt Allele. NCI Thesaurus. Code C49388.

Human GLS2 wild-type allele is located within $12 q 13$ and is approximately $17 \mathrm{~kb}$ in length.

This allele, which encodes glutaminase liver isoform, mitochondrial protein, is involved in the hydrolysis if L-glutamine. Expression of the GLS2 gene is induced during acidosis. 